\title{
Emerging Medico-legal Issues Novel to COVID Era
}

\author{
Neeraj Nagpal ${ }^{1}$
}

Department of Gastroenterology, Hope Gastrointestinal Diagnostic Clinic HCMC Pvt. Ltd., Mohali, Punjab, India

J Digest Endosc 2020;11:87-88

During this unprecedented pandemic we have been inundated with literature related to novel coronavirus disease 2019 (COVID-19) via webinars, e-publications, and social media in general. The article titled "Being Legally Safe in COVID-19 Era"1 is a very timely publication which looks at the regulatory and legal aspects of medical and endoscopic practice in India during this pandemic. Curfew, lockdown, red zones, social distancing, quarantine, Standard operating Procedures (SOPs), and penal action for noncompliance are words we have all become familiar with.

With no public health law in place, India is fighting COVID-19 Pandemic using a 123-year-old Epidemic Diseases Act, an older still Indian Penal Code of 1860 vintage, and a recent Disaster Management Act of 2005. Besides these, there are 483 notifications issued by the Government related to COVID-19 since January 17, 2020 till April 19, 2020. ${ }^{2}$ Over and above, these are various orders, guidelines, and rules made by various state governments and local authorities. Many of these are conflicting and are creating confusion even for doctors. Some doctors have had FIR (first information report) lodged against them for allegedly not complying with orders of local authority. ${ }^{3}$ Hospitals have been closed if a patient or staff is found to be COVID-19 positive. Though a state of emergency has not been declared yet but expanding the scope of "Internal Disturbances" suspension of Article 19 of Indian Constitution would be the next step if the COVID-19 is not contained by measures taken so far. ${ }^{4}$

Special circumstances justify special measures and when such extraordinary measures are undertaken, there is always a chance of errors resulting in collateral and unintended damage. All officials and authorities act during such emergency and unusual circumstances with a protection accorded to them for action taken in good faith. Section 73 of Disaster Management Act and Section 4 of Epidemic Diseases Act specifically mention that no suit or legal proceeding will lie against an officer for action taken in good faith under these Acts. Unfortunately, even in these times doctors have not be given any relief from prosecution for alleged grievance of patients or for noncompliance of Provisions of Consumer Protection Act, Indian Medical Council Act (National Medical Commission), Indian Penal Code,

\author{
Address for correspondence Neeraj Nagpal MBBS, MD (Med) FIMSA \\ Hope Gastrointestinal Diagnostic Clinic HCMC Pvt. Ltd., SCO 1066, \\ Sector 123, Mohali 140301, Punjab, India \\ (e-mail: hopeclinics@yahoo.com).
}

Clinical Establishment Act, PCPNDT Act, Biomedical Waste Management Rules, etc., even though they are working in exceptional circumstances. By following law, we are neglecting our regular patients putting them at risk of complications, exposing our staff, and non-COVID-19 patients to COVID-19 positive, and managing the patients of COVID-19 with limited resources at our disposal. Similarly telemedicine which so far was not permitted in India by Honorable Supreme Court, ${ }^{5}$ as well as the Indian Medical Council Regulations 2002, has now been permitted but will open new dangers for doctors who venture into this arena. The professional acts of doctors during this period is going to be evaluated and adjudicated by the leisurely judicial process many years later.

There is also the issue of requisitioning of private resources including premises, equipment, vehicles, and manpower which has already been done in Andhra Pradesh where 58 private hospitals have been taken over by the Government. ${ }^{6}$ Authorities have the power to requisition services of private doctors, their establishments, and vehicles if it so desires. States where Clinical Establishment Act is notified already possess a great leverage over private health care facilities and realizing this Punjab Government, recently during the COVID-19 epidemic, has notified the Clinical Establishment Act which was stalled for long.

According to Section 56 of Disaster Management Act, any officer on whom any duty has been imposed under this Act and who ceases or refuses to perform or withdraws himself from the duty without express written permission of his superior, an imprisonment up to 1 year can be applied. Government doctors who take unsanctioned sick leave or private doctors requisitioned who refuse to join duty need to be aware of the consequences.

Doctors, especially those who own or manage small and medium health care establishments will need to further be wary of falling foul of labor laws. They cannot do elective procedures, they may have closed the OPDs, or even the hospital but by law, they cannot lay off staff members or deduct their salary for days when the staff member has been absent from duty. The issue of consent has been elaborately discussed in the article by Dr. Setya Ashwin Kumar; however, the issue
DOI https://doi.org/ $10.1055 / \mathrm{s}-0040-1712546$ ISSN 0976-5042.
License terms

()(1) $\Theta \circledast$ 
of medical record keeping needs special mention. Writing notes while wearing gloves and personal protective equipments (PPEs) is cumbersome and not hygienic. It is also not feasible to write all notes at the end of duty shift because law demands medical records to be written contemporaneously. Similarly, use of keyboard while wearing gloves is difficult and likely to transmit infection.

Medical professionals are precious national resource in these exceptional circumstances of pandemic and they should have a mind free of any stress of violence against them or litigations in future at least for the duration of the pandemic. Government needs to urgently look into this aspect and protect doctors not only from violence but also from suits or legal proceedings for cause of actions arising during the period that Disaster Management Act remains notified.

\section{Conflict of Interest}

None declared.

\section{References}

1 Setya AK. Being legally safe in COVID era. J Digest Endoscopy 2020;11;83-86

2 Major notifications. Available at: https://prsindia.org/covid-19/ notifications. Accessed April 20, 2020

3 Panchkula: Doctor booked for hiding patient information. Available at: https://timesofindia.indiatimes.com/city/chandigarh/panchkula-doctor-booked-for-hiding-patient-information/articleshow/75214048.cms. Accessed April 20, 2020

4 COVID-19 crackdown: how far can the government go? Available at: https://www.indialegallive.com/top-news-ofthe-day/news/covid-19-crackdown-how-far-can-the-government-go-93763. Accessed April 20, 2020

5 Martin F D'souza vs Mohad Ishfaq (2009) 3; SCC 1

6 Should Modi govt take over private hospitals to fight coronavirus pandemic like Spain? Available at: https://www. indiatoday.in/news-analysis/story/should-modi-govt-takeover-private-hospitals-to-fight-coronavirus-pandemic-likespain-1665059-2020-04-09. Accessed April 20, 2020 